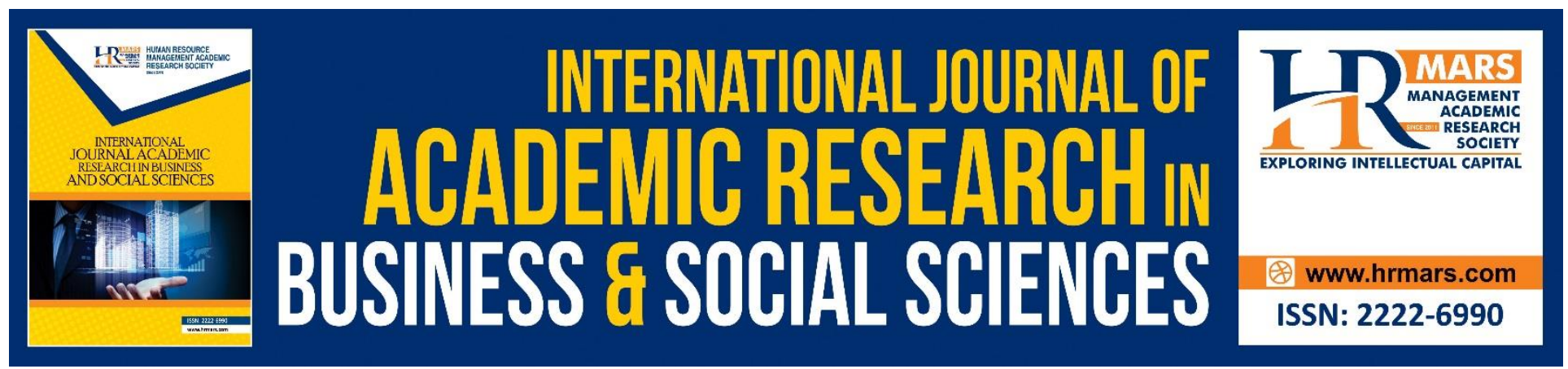

\title{
Socio-Demographic Differences on Youth Behavioural Intention to Engage in Agriculture
}

Jeffrey Lawrence D'Silva, Duzhailmi Dahalan, Zeinab Zaremohzzabieh, Ismi Arif Ismail and Steven Eric Krauss @ Abd. Lateef

To Link this Article: http://dx.doi.org/10.6007/IJARBSS/v10-i15/8249

DOI:10.6007/IJARBSS/v10-i15/8249

Received: 06 September 2020, Revised: 10 October 2020, Accepted: 11 November 2020

Published Online: 30 November 2020

In-Text Citation: (D'Silva et al., 2020)

To Cite this Article: D’Silva, J. L., Dahalan, D., Zaremohzzabieh, Z., Ismail, I. A., \& Lateef, S. E. K. @ A. (2020). Socio-Demographic Differences on Youth Behavioural Intention to Engage in Agriculture. International Journal of Academic Research in Business and Social Sciences, 10(15), 284-291.

\section{Copyright: (c) 2020 The Author(s)}

Published by Human Resource Management Academic Research Society (www.hrmars.com)

This article is published under the Creative Commons Attribution (CC BY 4.0) license. Anyone may reproduce, distribute, translate and create derivative works of this article (for both commercial and non-commercial purposes), subject to full attribution to the original publication and authors. The full terms of this license may be seen

at: http://creativecommons.org/licences/by/4.0/legalcode

Special Issue: Youth and Community Wellbeing: Issues, Challenges and Opportunities for Empowerment V1, 2020, Pg. 284 - 291

Full Terms \& Conditions of access and use can be found at http://hrmars.com/index.php/pages/detail/publication-ethics 


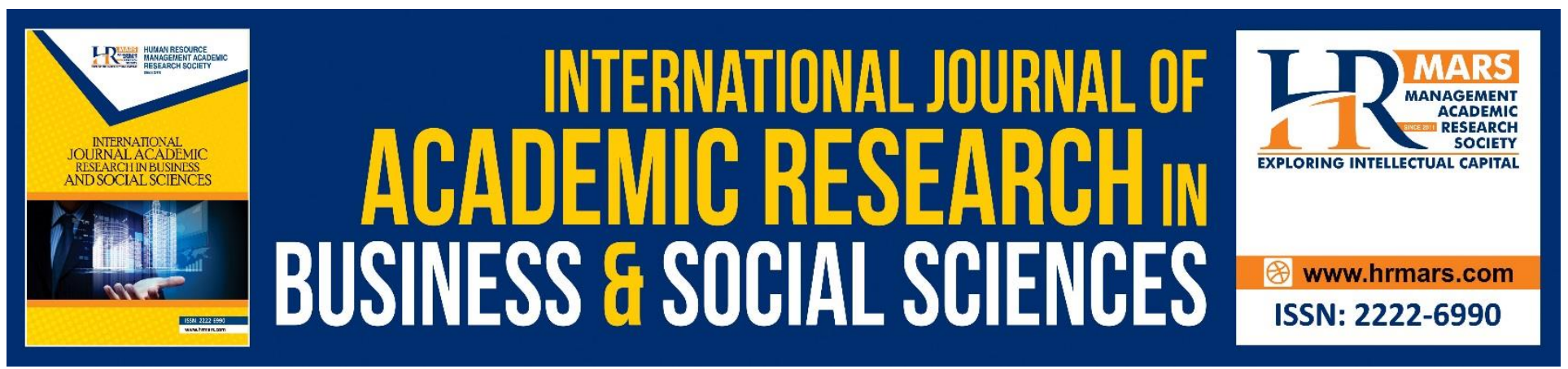

\title{
Socio-Demographic Differences on Youth Behavioural Intention to Engage in Agriculture
}

\author{
${ }^{1}$ Jeffrey Lawrence D'Silva, ${ }^{1}$ Duzhailmi Dahalan, ${ }^{1}$ Zeinab \\ Zaremohzzabieh, ${ }^{1,2}$ Ismi Arif Ismail and ${ }^{1,2}$ Steven Eric Krauss @ \\ Abd. Lateef \\ ${ }^{1}$ Laboratory of Youth Citizenship \& Leadership, Institute for Social Science Studies, Universiti Putra \\ Malaysia43400, UPM, Serdang, Selangor, Malaysia, ${ }^{2}$ Faculty of Educational Studies, Universiti Putra \\ Malaysia, 43400, UPM, Serdang, Selangor, Malaysia \\ Email: jld@upm.edu.my
}

\begin{abstract}
Agriculture will always remain as an important industry since it is linked to food security and economic stability of a nation. However, the sector's contribution to gross domestic product of many nations has been at a snail's pace. To overcome this malaise, youth need to be engaged in the agriculture sector. The aim of this study is to determine the socio-demographic factors that influence youth behavioural intention to participate in the agriculture sector. This is a quantitative study and the data was collected from 488 youth majoring in agriculture and studying in local institutions in Malaysia. The study identified that the majority of the youth possess a high behavioural intention towards agriculture. Further analysis revealed that there were significant differences in behavioural intention for gender and location. Some recommendations are put forward to further boost youth participation in agriculture.
\end{abstract}

Keywords: Socio-Demographic Differences, Agriculture, Behavioural Intention, Career, Youth

\section{Introduction}

The sustainability of the agriculture sector is undoubtedly dependable greatly on the involvement of youth as the force to boost the productivity of the agriculture sector. However, recent data draws a bleak picture as Paisley (2013) argues that currently, the younger generations are unwilling to involve in agriculture and consequently their interests in making agriculture as a field of profession is diminishing. As a result, in many countries, today agriculture is predominantly a sector that is monopolized by the ageing population.

Malaysia achieved independence in 1957 and soon after achieving independence the agriculture sector was the engine of growth for the nations' economy. There were ample natural 
INTERNATIONAL JOURNAL OF ACADEMIC RESEARCH IN BUSINESS AND SOCIAL SCIENCES

Vol. 10, No. 15, Youth and Community Wellbeing: Issues, Challenges and Opportunities for Empowerment V1. 2020, E-ISSN: 2222-6990 @ 2020 HRMARS

resources and unutilized land and this was a great blessing for the country to prosper economically based on the production of primary commodities. Many of the citizens then regarded agriculture as the source of living and the country was thriving in the agriculture sector and had become world's top producers of rubber and palm oil. Besides, many local commodity conglomerates emerged and contributed extensively to the development of the agriculture sector. Meanwhile, smallholders were the major players for crops such as rice, fruits, and vegetables.

Soon industrialization began to play a major role in the Malaysian economy and consequently as years passed by, with the advent of the global race of industrialization and the implementation of the Export-Oriented Industrial Strategy saw the rise of the manufacturing industry with the focus on electronics and textiles. This caused the agriculture sector to lag behind as employment was focused on manufacturing industry. The statistics in 2017 show that the manufacturing sector generated RM1.27 trillion involving 2.2 million individuals in the country, while the agriculture sector made RM96 billion in revenue with the involvement of 835,974 persons (DOSM, 2020). Meanwhile, in terms of employment in agriculture, Figure 1 clearly shows that the number had been dwindling from 1991 to 2019 with agriculture being predominantly controlled by the adult group.

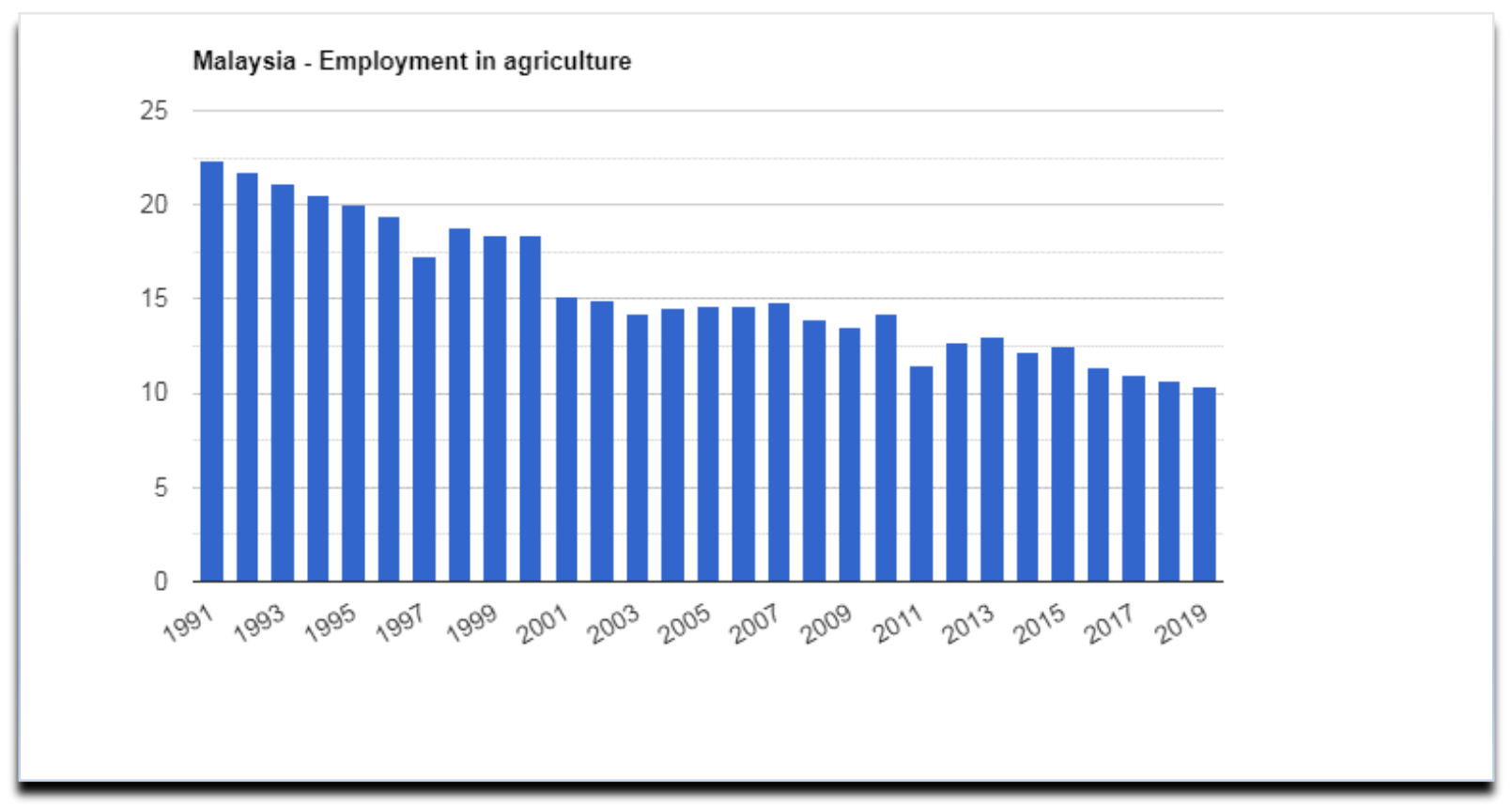

Figure 1: Data on Malaysia Employment in Agriculture

Undoubtedly, Malaysia realizes the importance of agriculture for food consumption and security and the outlook for the agriculture sector for the next decade appears promising despite global challenges. The formation of two ministries, the Ministry of Agriculture and Agro-based Industry and the Ministry of Primary Industries, is a clear indication on the seriousness of the Malaysian government to boost progressive agriculture transformation. As a result, between April 
and June 2019, the agricultural sector contributed $4.2 \%$ to the total economy as revenue and this is seen as positive.

To ensure the sustainability of the agriculture sector, youth should be playing a prominent role. In Malaysia, based on the amendment to the Youth Societies and Youth Development Act (Amendment) 2019 (Act 668), youth is defined as a person aged between the ages of 15 to 30 years old (NST, 2019). Adenan et al. (2015) state that in Malaysia, the youth represents a total of $43.8 \%$ of the population and out of this less than $20 \%$ are involved in jobs related to agriculture. This is an alarming figure and surely more concrete efforts are needed to encourage our youth to make agriculture as the career of choice. Various reasons have been identified such as negative perception of the younger generation on the agricultural activities especially traditional farming is an unattractive proposition. This is further contributed to the ways in which agriculture has been practiced by the older generation so agriculture reflects a poor social status and as a result youth seek seemingly better alternatives in other sectors. Besides, researchers also identified that youth have a negative attitude towards agriculture (D'Silva et. al, 2010). However, on the contrary to the findings of previous studies, result of a study conducted in by Man (2008) showed that although Malaysian youth have a negative attitude towards agriculture they believe agriculture can generate a good income.

Undoubtedly, more studies need to be carried out to identify the behavioural intention of youth to make agriculture as their career. Behavioural intention of individuals as depicted in the Theory of Planned Behaviour and the Theory of Reasoned Action is defined as a person's perceived likelihood or "subjective probability that he or she will engage in a given behaviour". Sociodemographic differences could play a significant role in determining youth's engagement in the agriculture sector (Veettil et al., 2020; Ball, 2020; Kvartiuk et al., 2020). Specifically, past studies have shown the influence of gender and location on behavioural intention Therefore, this study aims to investigate the socio-demographic differences on youth behavioural intention to engage in agriculture as their career choice.

\section{Methodology}

This study employed a quantitative methodology involving 488 youth aged 19-25 years representing five zones in Malaysia, namely, northern, centre, southern, east-coast and Borneo. The items for the behavioural intention dimension was derived from studies done by Wijerathna et al. (2015) and it constitutes eight items based on a five-point Likert scale. Among the items are as follows: (i) I prefer to be involved in the agricultural sector rather than in other sectors, (ii) My professional goal is to get involved in jobs related to the agricultural sector, (iii) I have a very serious intention to venture into the agriculture sector, (iv) I am willing to do anything to venture into the agriculture sector. The Cronbach alpha obtained was .948 indicating that the items are reliable. The data collection was completed within one month involving students attached to agriculture institutions. Data analysis was carried out using the SPSS software. 
INTERNATIONAL JOURNAL OF ACADEMIC RESEARCH IN BUSINESS AND SOCIAL SCIENCES

Vol. 10, No. 15, Youth and Community Wellbeing: Issues, Challenges and Opportunities for Empowerment V1. 2020, E-ISSN: 2222-6990 @ 2020 HRMARS

\section{Results and Discussion}

Table 1 shows the behavioural intention of youth to engage in the agriculture industry. The mean score obtained was 3.92 ( $S D=.78$ ). Accordingly, in Table 2, there is a breakdown based on the category of low, moderate and high. The results revealed that $65.8 \%$ of the youth are at the high level followed by $30.5 \%$ at the moderate level. Around $3.7 \%$ of the youth are at the low level.

Table 1: Mean Value of Behavioural Intention

Descriptive Statistics

\begin{tabular}{|l|c|c|c|}
\hline & N & Mean & Std. Deviation \\
\hline BI & 488 & 3.9216 & .77888 \\
Valid N (listwise) & 488 & & \\
\hline
\end{tabular}

Table 2: Behavioural Intention Based on Category

BI Category

\begin{tabular}{|c|c|c|c|c|c|}
\hline & & Frequency & Percent & Valid Percent & $\begin{array}{c}\text { Cumulative } \\
\text { Percent }\end{array}$ \\
\hline \multirow[t]{4}{*}{ Valid } & Low & 18 & 3.7 & 3.7 & 3.7 \\
\hline & Moderate & 149 & 30.5 & 30.5 & 34.2 \\
\hline & High & 321 & 65.8 & 65.8 & 100.0 \\
\hline & Total & 488 & 100.0 & 100.0 & \\
\hline
\end{tabular}

An independent sample t-test was carried out to determine whether there is a significant difference in behavioural intention between male and female youth. The results, as in Table 3, depict that in terms of descriptive statistics, the mean scores obtained by the male respondents were higher compared to the female students. Further analysis as in Table 4 showed that the $p$-value obtained was less than the alpha value set at .05. This means there is a significant difference in the behavioural intention to engage in agriculture industry between male and female youth. Similar results were also obtained by Yu and Wang (2018) that carried out a study among university students in Taiwan.

Table 3: Mean Values on Behavioural Intention for Male and Female Group Statistics

\begin{tabular}{|ll|c|c|c|c|}
\hline & gender & $\mathrm{N}$ & Mean & Std. Deviation & $\begin{array}{c}\text { Std. Error } \\
\text { Mean }\end{array}$ \\
\hline $\mathrm{BI}$ & male & 208 & 4.1683 & .67012 & .04646 \\
& female & 280 & 3.7384 & .80418 & .04806 \\
\hline
\end{tabular}

Table 4: Independent Sample Test on Behavioural Intention between Male and Female 
INTERNATIONAL JOURNAL OF ACADEMIC RESEARCH IN BUSINESS AND SOCIAL SCIENCES

Vol. 10, No. 15, Youth and Community Wellbeing: Issues, Challenges and Opportunities for Empowerment V1. 2020, E-ISSN: 2222-6990 @ 2020 HRMARS

Independent Samples Test

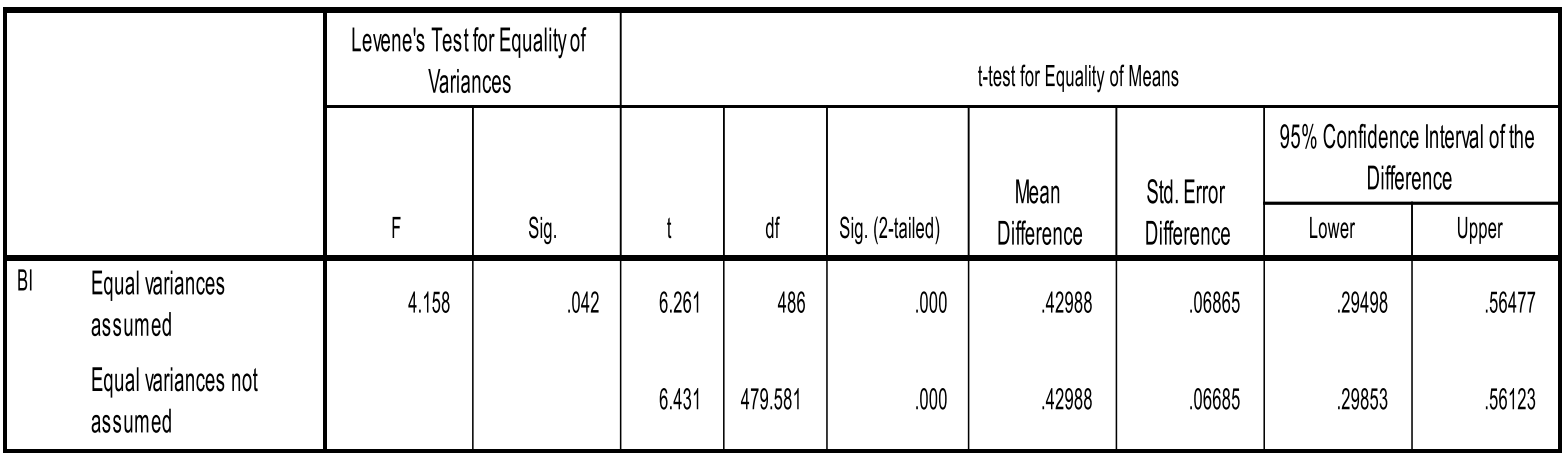

Another test was carried to determine whether location had a difference in behavioural intention of youth to engage in agricultural industry. The descriptive statistics show that youth coming from rural location have a greater mean score compared to the urban youth (Table 5). Consequently, the inferential statistics based on the independent samples t-test displayed that the differences are significant as in Table 6. The results indicate that to a certain degree the growth of the agricultural sector is very much aligned to the youth originating from rural areas. This is in line with a recent study carried out by Thangadurai et al. (2020) that identified young farming communities in rural districts like Dharmapuri were more inclined towards farming and consequently it increased their livelihoods as well as health.

Table 5: Mean Values on Behavioural Intention for Urban and Rural Location Group Statistics

\begin{tabular}{|c|c|c|c|c|c|}
\hline & Permenant Residence & $\mathrm{N}$ & Mean & Std. Deviation & $\begin{array}{c}\text { Std. Error } \\
\text { Mean }\end{array}$ \\
\hline \multirow[t]{2}{*}{$\mathrm{BI}$} & urban & 235 & 3.8601 & .77058 & .05027 \\
\hline & rural & 253 & 3.9788 & .78370 & .04927 \\
\hline
\end{tabular}

Table 6: Independent Sample Test on Behavioural Intention between Urban and Rural Location

Independent Samples Test

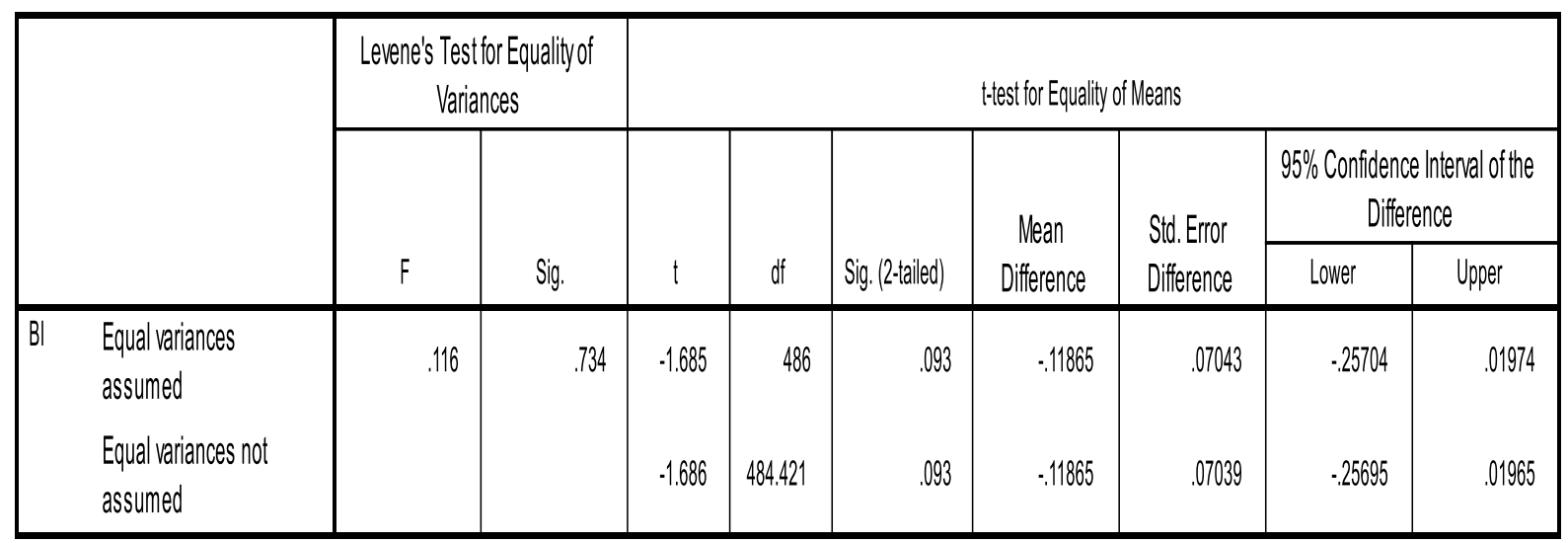


INTERNATIONAL JOURNAL OF ACADEMIC RESEARCH IN BUSINESS AND SOCIAL SCIENCES

Vol. 10, No. 15, Youth and Community Wellbeing: Issues, Challenges and Opportunities for Empowerment V1. 2020, E-ISSN: 2222-6990 @) 2020 HRMARS

Another interesting item posed to the respondents was the choice of the sector that they would prefer to be in as future employment. The results show that $53.1 \%$ of the respondents preferred to work in the government sector followed by $26.6 \%$ as self-employed. Around $20.3 \%$ of the respondents are keen to work in the private sector. The present study indicated that the government's efforts in creating awareness among youth to be entrepreneurs are gaining positive momentum. Thus, agriculture educators need to continue to equip their students with entrepreneurial skills and provide positive experiences so that these youth would eventually become agriculture job-creators instead of job-seekers.

Table 7: Youth Future Employment

Future employment

\begin{tabular}{|ll|r|r|r|r|}
\hline & & & Cumulative \\
Percent
\end{tabular}

\section{Conclusion}

This study provides an in-depth understanding of youth behavioural intention to engage in the agricultural industry. Based on the results, the study has shown that the behavioural intention among youth to engage themselves in agricultural industry is high. What might be needed now would be to have more labour-saving technologies to boost the agriculture sector. Moreover, the study depicts that the agriculture sector is very much aligned to male and rural youth. It is recommended that future studies could be carried out to identify how the agriculture sector could adopt new technologies as this is vital to attract youth participation in the agriculture sector and to overcome the heavy reliance on undocumented workers.

\section{Acknowledgements}

This research was supported by the Research Management Centre, Universiti Putra Malaysia (GPB/2018/9597700).

\section{References}

Adenan, A., Subramaniam, D., and Aminudin, S. I. M. (2015). Policy on land for agriculture projects in Malaysia for the young agropreneur through blue ocean strategy. Available: http://www.fftc.agnet.org/library.php?func=view\&style=type\&id=20161011112908.

Ball, J. A. (2020). Women farmers in developed countries: a literature review. Agric Hum Values 37, 147-160. https://doi.org/10.1007/s10460-019-09978-3

D'Silva, J. L., Shaffril, H. A. M., Uli, J., and Samah, B. A. (2010). Socio-demography factors that influence youth attitude towards contract farming, American Journal of Applied Sciences, 10(19), 23102315. 
INTERNATIONAL JOURNAL OF ACADEMIC RESEARCH IN BUSINESS AND SOCIAL SCIENCES

Vol. 10, No. 15, Youth and Community Wellbeing: Issues, Challenges and Opportunities for Empowerment V1. 2020, E-ISSN: 2222-6990 @) 2020 HRMARS

Department of Statistic Malaysia (2020). Agriculture. Available: https://www.dosm.gov.my/v1/index.php?r=column/ctwoByCat\&parent_id=45\&menu_id=Z0 VTZGU1UHBUT1VJMFIpaXRRR0xpdz09

Kiriakidis, S. (2015). Theory of Planned Behaviour: The intention-behaviour relationship and the perceived behavioural control relationship with intention and behaviour, International Journal of Strategic Innovative Marketing, 3, 40-51.

Kvartiuk, V., Petrick, M., Bavorova, M., Bednaříková, Z., \& Ponkina, E. (2020). A Brain Drain in Russian Agriculture? Migration Sentiments among Skilled Russian Rural Youth, Europe-Asia Studies, 72:8, 1352-1377, DOI: 10.1080/09668136.2020.1730305

Man, N. (2008). Youths farmer's perception towards the needs of agriculture education, Journal Pembangunan Belia, 1, 99-114.

News Strait Times News Paper. (2019). 'Youth' now defined as those between 15 and 30. Available: https://www.nst.com.my/news/nation/2019/07/501288/youth-now-defined-those-between15-and-30.

Paisley, C. (2013). Commentary - engaging youth in agriculture. Investing in our future. Available: https://youngfamersfoundation.wordpress.com/2014/06/13/engaging-youth-in-agricultureinvesting-in-our-future/.

Ridha, R. B., and Wahyu, B. (2017). Entrepreneurship intention in agricultural sector of young generation in Indonesia, Asia Pacific Journal of Innovation and Entrepreneurship, 11(1), 76-89.

Thangadurai, R., Shanmugam, P. S., Vennila, M. A., \& Sivakumar, C. (2020). Success Story on Backyard Poultry Rearing under ARYA Programme. Biotica Research Today. 2(9), 859-861.

Veettil, P. C., Raghu, P., Mohapatra, B., \& Mohanty, S. (2020). Gender differences in rice value chain participation and career preferences of rural youth in India, Development in Practice, DOI: 10.1080/09614524.2020.1804840

Wijerathna, R. M. S., Wickramasuriya, H. V. A., and Marambe, B. (2015). Factor predicting the intention of academics of faculties of agriculture in the state universities in Sri Lanka to engage in outreach activities, Tropical Agricultural Research, 26(2), 285-293.

$\mathrm{Yu}$, T. L., and Wang, J. H. (2019). Factors affecting social entrepreneurship intentions among agriculture university students in Taiwan, International Food and Agribusiness Management Review, 22:1, 107-118. 